\title{
Canola Oil
}

National Cancer Institute

\section{Source}

National Cancer Institute. Canola Oil. NCI Thesaurus. Code C1036.

Vegetable oil developed from rapeseed plant. 